\title{
Networks and Bibliographic Standardization
}

At the conference on Interlibrary Communication and Information Networks held recently at Airlie House, a group of librarians, computerniks, and communication experts gathered to review the state of the art of network development in the United States, to assess problems and prospects, and to provide a sense of direction to the eventual implementation of a national network system. Groups were established to explore these topics: network needs and development; network services; network technology; network organization; and network planning.

After a week of concentrated, exhausting effort, the groups offered an impressive array of recommendations. One obvious conclusion is that we are a long way from achieving the goal of a national network system. The technology may be available, but there are many problems to be solved before a national system becomes a reality. Among the yet unresolved problems are: a means of regulating large scale networks to ensure the public good; securing large sums of money to train people to operate and manage networks; and promoting federal and state enabling legislation, where necessary.

One old problem which reared its ugly head time and time again was the question of how to achieve bibliographic standardization. We have given much lip service to the need for standardization, while in fact we have gone about our separate ways. Anyone who has been involved with cooperative programs is well aware of the bibliographic spaghetti we have created.

One might have assumed that with the introduction of MARC II, libraries would have taken steps to insure interinstitutional compatibility in order to avoid the high cost of inputting records locally. Not so, according to Barbara Markuson, who reported, with a hint of deep frustration, that over three million records have already been converted into machine-readable form, and in spite of all caveats, these records are largely incompatible.

The national network will probably be composed of many local and regional networks linked together, so that compatibility will be essential for bibliographic data interchange. While the next few years may not be our last opportunity to solve the problem of standardization, time is against us. The longer we procrastinate, the less will local and regional networks be able "truly" to exchange bibliographic data.

It was suggested by several people attending the conference that in order to insure standardization, those agencies which accept federal funds to support network development should be required, as a condition of the grant, to agree to adhere to professionally agreed upon standards. While I shudder at federal control of most things, at the moment, realistically speaking, there seems to be no other way to achieve bibliographical standardization except by establishing a program at the national level.

Richard M. Dougherty 


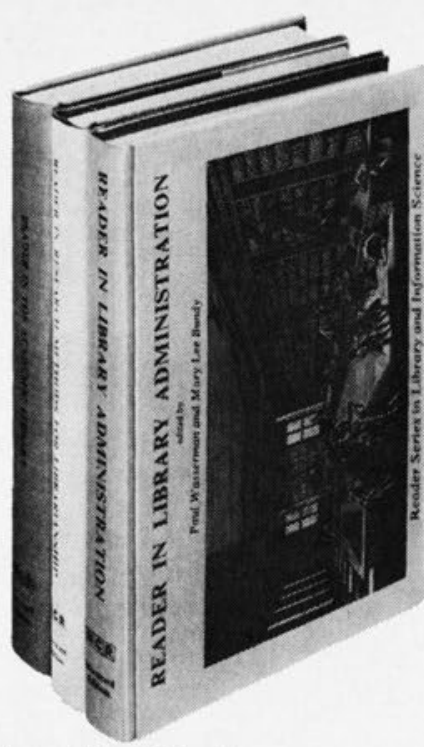

Reader in Library Administration

Edited by Paul Wasserman and Mary Lee Bundy

Designed to provide insight into the organizational dynamics of libraries, this volume includes essays by specialists in library administration as well as by management experts in other fields such as Edward Litchfield, Peter Drucker, Amitai Etzioni, and Herbert Simon. Reader in Library Administration focuses upon administrative processes rather than upon techniques and is not intended to provide solutions or formulae. Rather, it shows the complexity of the modern library organization and identifies important issues facing administrations.

$403 \mathrm{pp}$.

hardbound

$\$ 10.95$

\section{Reader in Research Methods for Librarianship}

Edited by Mary Lee Bundy and Paul Wasserman

This volume is concerned not only with the design and conduct of research but also with the philosophical and social implications of research on librarianship. It includes varied academic treatment of research, illustrative examples of research theories, and field accounts as well as samples of actual research instruments. Contributors include distinguished social scientists such as David Riesman, C. Wright Mills, Arthur Vidich, Peter Blau, and William Foote Whyte as well as library specialists in research methods.

$363 \mathrm{pp}$.

hardbound

$\$ 11.95$

\section{Reader in the Academic Library}

Edited by Michael M. Reynolds

The emphasis of the book is to illustrate problems representative of the nature of higher education and of library administration, as opposed to describing operational innovations or giving histories of particular libraries. Among the librarians whose articles appear in the book are Stephen A. McCarthy, Andrew H. Horn, Robert B. Downs, Maurice Tauber, Jesse H. Shera, and Herman H. Fussler. Among those from other fields are Clark Kerr, John D. Millett, Edward C. Banfield, Charles E. Bidwell, Peter Sammartino and Ben Euwema. 379 pp. hardbound

$\$ 10.95$

\section{Reader Series in Library and Information Science}

This series brings together, in convenient volumes, key articles required for a comprehensive view of major topics in library science today. The Reader Series, which is being developed under the direction of Dr. Paul Wasserman, professor at the University of Maryland School of Library and Information Services, includes relevant material from a wide range of disciplines in addition to the traditional literature of librarianship. These volumes are invaluable as ... texts for courses in library science.... supplementary course reading .... a focus for seminar discussion ... the basis for individual study.

\section{\begin{tabular}{|l|l|l|}
\hline N|C & MICROCARD EDITIONS \\
\hline
\end{tabular}} 901 TWENTY-SIXTH STREET, N.W., WASHINGTON, D.C. 20037

Please send me copies of each of the first three volumes of the Reader Series in Library and Information Science at the special price of $\$ 30$ per set, post-paid. Payment must accompany orders at this Special Ratemy check for $\$$ is enclosed.

I prefer to order single volumes as indicated below:

$\square$ Please send me__ copies of Reader in Library Administration at $\$ 10.95$ each ( $\$ 9.95$ if payment is enclosed).

$\square$ Please send me__ copies of Reader in Research Methods in Librarianship at $\$ 11.95$ each ( $\$ 10.95$ if payment is enclosed).

$\square$ Please send me___ copies of Reader in the Academic Library at $\$ 10.95$ each ( $\$ 9.95$ if payment is enclosed).

Payment is enclosed.

Please bill me for the books indicated above plus a small charge for postage and handling.

NAME

TITLE

ORGANIZATION

ADDRESS

CITY

STATE

ZIP

Dept. CR7-N 